\title{
European judicial training in the field of environmental law
}

\section{Monika Krivickaite ${ }^{1}$}

(C) ERA 2015

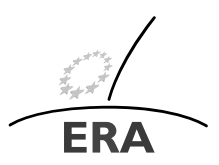

EUROPÄISCHE RECHTSAKADEMIE ACADEMY OF EUROPEAN LAW ACADEMIE DE DROIT EUROPEEN ACCADEMIA DI DIRITTO EUROPEO TRIER - TREVES - TREVIRI

\section{Introduction}

Most studies and analyses of European Union law remain confined to the European level-an approach which leaves the impact of fundamental European doctrines within domestic jurisdictions much less well known and raises the question of the relationship between consistency in the formulation of European Union law rules by a single supranational court and the existence of different legal traditions, court systems, remedies and legal proceedings as well as diverse legal vocabularies at national level. ${ }^{1}$ Recognising that European Union law is today the main source in the development of Member States' national law, the European Commission has repeatedly emphasised that legal practitioners in the European Union-from judges, prosecutors, lawyers and notaries to court staff and bailiffs-must be aware of the European Union law aspects of their daily work in order to apply the law correctly. More importantly they need to have trust in each other's legal systems so that cross-border judicial proceedings work smoothly ${ }^{2}$ — not only in the area of civil or criminal law, but also with regard to the implementation of European environmental law. The capacity of national courts to guarantee the correct and efficient application of European environmental law is an essential factor in addressing the legitimate expectations of

\footnotetext{
${ }^{1}$ Macror; Moreno [2], p. 3.

${ }^{2}$ Verra Jourová, Commissioner for Justice, Consumers and Gender Equality, Introduction to the third edition of the report on European judicial training, accessible under: http://ec.europa.eu/justice/criminal/ files/final_report_2014_en.pdf.
}

$\bar{\square}$ M. Krivickaite, Deputy Head of Section-Public Law mkrivickaite@era.int

1 Metzer Allee 4, 54295 Trier, Germany 
European Union citizens in this area. In this respect, national judges play a key role in ensuring that European Union environmental law is correctly applied. ${ }^{3}$

A glance at the statistics produced by the European Commission's Environment Directorate-General reveals that the implementation of European environmental law by the Member States constitutes the biggest legal challenge for the European Union with regard to the transposition of European legal instruments into national law. At 334 infringement files, DG Environment has the highest number of open cases among all Directorates General of the European Commission. With the total number of infringement procedures being handled by the Commission at the end of 2014 standing at 1607 , more than $20 \%$ of Commission infringement actions are being handled by DG Environment. The majority of Member States are thus accused of insufficient or delayed transposition of a significant number of environmental directives and confronted with challenges regarding the application of certain environmental regulations. In such circumstances, the role of national judges in upholding European environmental law is crucial, but at the same time complicated. ${ }^{4}$ The judge has to make an in-depth analysis of European environmental law, taking into account the ever-growing body of case law of the CJEU. However, most judges in charge of environmental cases are not specialists in European environmental law, since this particular domain is part of the administrative law sector and national judges dedicate only a limited amount of time to this category of case. Thus, non-specialised judges need the information and training that will provide them with the key elements required to access this subject matter, which involves not only legal, but usually also complex technical challenges. Consequently, this has an impact in terms of the need to reinforce the competences and training of judges in environmental matters.

\section{The "Co-operation with national judges in the field of environmental law" programme}

Bearing in mind that European Union law today is the main legal source in the development of Member States' national environmental law and recognising the need to reinforce cooperation with national judges, the European Commission's Environment Directorate-General launched a special programme for just this purpose. Since 2012, the Academy of European Law (ERA) has been contracted to develop training modules on various topics of European Union environmental law as well as to organise workshops and seminars on the implementation of European Union environmental law. The main goal of the second phase of the programme Co-operation with national judges in the field of environmental law (2012-2016) is to further develop, improve and ensure the sustainability of the programme for co-operation with national judges in the field of environmental law established during the last four years.

According to the third edition of the report on European judicial training, in 2013 more than 94,000 legal professionals were trained in European Union law or the national law of another European Union Member State. This is more than in previous

\footnotetext{
${ }^{3}$ Garcia; Heermann; Kreins; Lavrysen; Tiberghien [1], pp. 221-233 (221).

${ }^{4}$ Ibid.
} 
years and exceeds the European Commission's annual target of training $5 \%$ of legal practitioners in the European Union per year (which would equate to training around 70,000 individuals). ${ }^{5}$ The goal is to train half of all of the legal professionals in European Union law by $2020 .{ }^{6}$ For around 22,000 of the above-mentioned legal professionals, training on European Union law or the law of another Member State was co-funded by the European Union. ${ }^{7}$ ERA, implementing the project $\mathrm{Co}$ operation with national judges in the field of environmental law and having been awarded not only operating but also action grants under several other financial programmes over the last few years, is contributing to the achievement of this target. In order to do so in an innovative and value-added manner, ERA decided to adopt a very practical approach to European judicial training and proceed with the development of standardised training materials which will be reusable in future training activities. ${ }^{8}$

\section{Training modules}

The implementation of the Co-operation with national judges in the field of environmental law project involves not only the conception and development of the training modules, the organisation and implementation of the workshops targeting national judges around the European Union, but also the dissemination of their results, ensuring their international dimension and, more important, the sustainability of the training materials. The specific modules are therefore designed in a way to be directly used by judicial training institutions across Europe to implement training events according to the needs they identify and have a multiplier effect, which should be of interest also to non-judicial training actors. Most importantly, the modules strengthen application skills and promote the knowledge of European environmental law in this area much more efficiently than an individual training event could ever do.

To this date, three separate and independent training modules in the area of European Union environmental law have been developed by ERA: "EU Industrial Emissions", "Interaction between the Environmental Impact Assessment and the Nature Directives" and "Procedural and Participatory Rights in Environmental Matters". Each of the training packages is accessible by any party or institution interested in organising future training with duration of 2.5 days in the area of European environmental law. All training modules include a trainer's manual with information and guidelines on how to organise a workshop implementing the module, an introductory e-learning course, background materials for the recipients of the training and practical exercises with their suggested solutions, to be used in implementing workshops, as well as a stand alone e-learning course.

\footnotetext{
${ }^{5}$ Third edition of the report on European judicial training available under: http://ec.europa.eu/justice/ criminal/files/final_report_2014_en.pdf.

${ }^{6}$ European Commission, Press release, Brussels, 13 September 2011 (IP/11/1021) accessible under: http:// europa.eu/rapid/press-release_IP-11-1021_en.htm?locale=en\#_blank.

${ }^{7}$ Third edition of the report on European judicial training available under: http://ec.europa.eu/justice/ criminal/files/final_report_2014_en.pdf.
}

${ }^{8}$ See the Editorial by Patta [3], pp. 319-324. 
The so called "user's pack" contains all the training material for a legal professional wishing to acquire comprehensive knowledge on the specific topic covered by the respective training module. The user's pack is always made available to all workshop participants once they are at the training course, usually in electronic form, as this allows an easy, practical and environmentally-friendly use of the material and facilitates access to online sources and tools.

Certain elements of the user's pack are, however, also provided in advance (e.g., access to the e-learning course), in order to allow participants to prepare better for the workshop, or in hardcopy (e.g., the workshop exercises), so that they can easily be used during the workshop. Of the utmost importance of the user's pack is the blended e-learning course, providing a first overview of the subject matter, allowing end-users to familiarise themselves with the scope and objectives of the workshop and ensuring a minimum level of background knowledge of all participants before taking the course. Furthermore, the user's pack includes links to the most relevant European and international legal instruments in the specific areas of European Union environmental law and related jurisprudence of the CJEU.

In addition to the background documents, every time an implementing workshop is organised, the trainers involved are asked to prepare their own supporting material, in the form of PowerPoint presentations, outlines, notes or full texts of their lectures. The trainers' contributions can then be used as a reference document for identifying the main points of the subject matter. Also a number of interactive exercises have been developed for the workshops implementing the project. The exercises are structured on the basis of case studies, giving participants the opportunity to develop specific skills and gain some practical experience with the application of the legal instruments in the field of European environmental law.

Finally, a stand-alone version of each course is provided to national judges and the national training institutes. The stand alone e-learning course has been developed mainly for judges who are, for various reasons, not able to attend the implementing workshops or the workshops organised by national training institutes. The stand-alone e-learning course is an "advanced" version of the blended e-learning course and includes all the presentations which were given during the implementing workshops-not only as PowerPoint presentations, but also as e-lectures, for which speakers have been filmed during the workshop. In each e-lecture, the film and PowerPoint presentation are shown online in a split-screen, together with supporting material such as background documentation. This comprehensive e-learning course corresponds to the learning time of a face-to-face workshop and provides all the elements needed to replace such a course.

In addition to the materials included in the "user's pack", training providers have access to the "trainer's pack" providing advice on how to make use of the training module and set up an implementing workshop. The trainer's pack in relation to each training module consists of the user's pack described above and the "trainer's manual". In the trainer's manual, all the materials included in the training module are presented in detail, so that their function and possible integration in a workshop are effectively explained. Input is offered on how to structure the training programme, and which methodology should be employed in each part of the course. The trainer's manual also provides advice on all the organisational aspects of implementing workshops, such as how to define the target group and select the trainers. The trainer's 
manual also includes a brief presentation of the training module's structure and the materials included in it; a detailed explanation of the objectives and possible scope of the different sub-sessions, as well as advice on which methodology to employ in each part of the course. This preliminary information can assist trainers to prepare better for the implementing workshop.

Finally, accessibility to training materials that ERA is developing is guaranteed through specially developed project web pages as well as through the ERA and European Judicial Training Network websites. Finalised training materials are uploaded and made freely accessible to all interested parties. ${ }^{9}$

\section{Implementing workshops}

To test, evaluate and update the developed training materials of the three training modules, various implementing workshops have been organised in the framework of the project "Co-operation with national judges in the field of environmental law". The workshops have been addressed to national judges and carried out with the support of cooperating partners - usually national judicial training centres or higher administrative courts - in various Member States. The main purpose of these workshops has been to raise awareness of European Union environmental law and policy and to provide a forum for the exchange of knowledge and experience. A further objective has been to involve the national judicial training centres in order to enhance, in the long term, the benefits of this European Union programme.

In 2013 and 2014 nine implementing workshops were held at ERA in Trier and in various Member States (Hungary, Spain, Romania, Lithuania and Portugal), which were organised with the support of the respective national judicial training centres. The cooperation partners were not only helpful with regard to the organisational aspects of the workshops but usually also offered their assistance by raising awareness of the workshop among the national judiciary. The two-and-a-half day workshops engaged participants in working groups to discuss specific European Union environmental law subjects and achieved an outstanding level of participation and information exchange between the members of the groups, which leads to the assumption that judges in Europe would welcome more opportunities to exchange views and to benefit from experiences in different European Union Member States.

\section{Prospects}

The recent new initiatives, both by judges and by the Commission, for developing co-operation among judges in Europe demonstrate that, more than before, national judges are open to compare and discuss practises in different Member States. ${ }^{10}$ The

\footnotetext{
${ }^{9}$ More information on the materials available regarding the training modules in the framework of the programme Co-operation with national judges in the field of environmental law can be found on the project's web page: www.era.int/environmental_law/.

${ }^{10}$ The same conclusion was also arrived at after the first phase of the Co-operation with national judges in the field of environmental law programme. See Garcia [1], pp. 221-233 (221).
} 
added value of judicial training at Union level is that of encouraging exchanges between the different Member States and legal traditions, as well as between national courts and the Commission in order to improve the uniform implementation of Union law.

\section{References}

1. Garcia Burgues, J., Heermann, W., Kreins, Y., Lavrysen, L., Tiberghien, F.: A Common Heritage: EU Environmental Law and National Judges. Journal for European Environmental \& Planning Law 7(2) (2010)

2. Macrory, J.H., Jans, R., Moreno, Molina, A.M.: National Courts and EU Environmental law (2013)

3. Patta, A.: European judicial training: promoting the development of standardised training materials and an interactive training methodology. ERA Forum 15(3), October (2014) 